Check for updates

Cite this: RSC Adv., 2019, 9, 676

Received 10th October 2018

Accepted 11th December 2018

DOI: $10.1039 / c 8 r a 08405 j$

rsc.li/rsc-advances

\section{Label-free quantitative proteomics to investigate the response of strawberry fruit after controlled ozone treatment $\dagger$}

\author{
Cunkun Chen, ${ }^{\text {ab }}$ Xiaojun Zhang, ${ }^{c}$ Huijie Zhang, ${ }^{d}$ Zhaojun Ban, ${ }^{e}$ Li Li $^{f},{ }^{f}$ Chenghu Dong, ${ }^{c}$ \\ Haipeng $\mathrm{Ji}^{\mathrm{C}}$ and Wentong Xue $\left(\mathbb{D}^{*}{ }^{* a b}\right.$
}

\begin{abstract}
To elucidate postharvest senescence in strawberry (Fragaria ananassa Duch. var. 'JingTaoXiang') fruit in response to ozone treatment at different concentrations $\left(0,2.144,6.432\right.$, and $10.72 \mathrm{mg} \mathrm{m}^{-3}$ ), a labelfree quantitative proteomic investigation was performed. Postharvest physiological quality traits including respiration rate, firmness, titratable acid, and anthocyanin content were characterized. The observed protein expression profile after storage was related to delayed senescence in strawberries. A total of 2413 proteins were identified in differentially treated strawberry fruits, and 382 proteins were differentially expressed between the four treatments on day 7 and the initial value (blank 0). Proteins related to carbohydrate and energy metabolism and anthocyanin biosynthesis, cell stress response, and fruit firmness were characterized and quantified. Ozone treatment at the concentration of $10.72 \mathrm{mg} \mathrm{m}^{-3}$ effectively delayed the senescence of the strawberry. The proteomic profiles were linked to physiological traits of strawberry fruit senescence to provide new insights into possible molecular mechanisms.
\end{abstract}

\section{Introduction}

Ozone is an unstable gas that will gradually break down into oxygen and has a unique smell, a strong oxidative capacity, and a broad spectrum of antibacterial properties in water and air. Because ozone and triatomic oxygen $\left(\mathrm{O}_{3}\right)$ effectively suppress bacteria, moulds, protozoa, and viruses, they are widely used to treat food for safe storage. ${ }^{1}$ The effect of ozone application on the quality of fresh fruits and vegetables is atmospherecontrolled and temperature-dependent. Some biochemical, physiological, and molecular approaches have described the physiological and pathological processes associated with fruit

${ }^{a}$ Beijing Advanced Innovation Center for Food Nutrition and Human Health, College of Food Science and Nutritional Engineering, China Agricultural University, Beijing, China. E-mail: 17806283010@163.com

${ }^{b}$ College of Food Science and Nutritional Engineering, China Agricultural University, Beijing, China

${ }^{c}$ National Engineering Technology Research Center for Preservation of Agricultural Products, Key Laboratory of Postharvest Physiology and Storage of Agricultural Products, Ministry of Agriculture of China, Tianjin Key Laboratory of Postharvest Physiology and Storage of Agricultural Products, Tianjin, China

${ }^{d}$ College of Food Engineering and Biotechnology, Tianjin University of Science and Technology, Tianjin, China

${ }^{e}$ Zhejiang Provincial Key Laboratory of Chemical and Biological Processing Technology of Farm Products, Zhejiang University of Science and Technology, Hangzhou, China

${ }^{f}$ Key Laboratory for Agro-Products Postharvest Handling of Ministry of Agriculture, Zhejiang Key Laboratory for Agro-Food Processing, College of Biosystems Engineering and Food Science, Zhejiang University, Hangzhou, China

$\dagger$ Electronic supplementary information (ESI) available. See DOI: 10.1039/c8ra08405j senescence under controlled ozone treatment storage. ${ }^{2}$ Progress has recently been made on the transcriptome and genome levels. ${ }^{3}$ However, the molecular mechanisms involved cannot be fully characterised by the existing transcriptome because the expression profile of the final gene product cannot be accurately predicted at the transcriptome or genome level. ${ }^{4}$ In addition, due to protein modifications that reflect changes in cell function, mRNA and gene expression analysis may be inconsistent with the functional protein. ${ }^{5}$

Recently, quantitative proteomics has been used by plant biologists to simultaneously screen several metabolic pathways that have undergone changes at the molecular level. ${ }^{6,7}$ Proteomic studies on fruits such as strawberries, ${ }^{8}$ tomatoes, ${ }^{7}$ pears, ${ }^{9}$ and grape plants ${ }^{\mathbf{1 0}}$ have shown that proteomic methods are useful in the study of fruit ripening, senescence, physiological diseases, and allergens. Nilo et al. successfully identified and quantified the cold stress-response proteins, such as NADPdependent isocitrate dehydrogenase and pectin methylesterase, of peach by a comparative two-dimensional (2-D) difference gel electrophoresis (DIGE) proteomic approach. ${ }^{\mathbf{1 1}}$ A large number of protein molecular markers associated with tolerance was detected using a two-dimensional gel electrophoresis (2DE) approach when strawberry was subjected to cold stress. ${ }^{12}$ Using a label-free quantitative proteomics method, 73 proteins related to energy metabolism and protein folding were detected in strawberries upon storage under low temperature and modified atmosphere. ${ }^{8}$ However, there have been few studies regarding proteomic changes related to ozone treatment for fruit storage (kiwifruit ${ }^{13}$ and tomato ${ }^{14}$ ). Additionally, the method 
of 2-DE is complicated to perform, and the accuracy is affected by many factors. ${ }^{15}$ No groups have investigated the proteomic changes of the postharvest strawberry treated with ozone.

Label-free proteomics is a method based on the intensity or spectral count of mass peaks and is convenient and reliable in proteomics studies. ${ }^{\mathbf{8 , 1 6 , 1 7}}$ Improvements in normalization methods have greatly improved the accuracy of label-free proteomics that rely on mass spectrometry stability. ${ }^{18}$ Moreover, the unlabelled method reduces experimental error and is more accurate compared with the labelling method, and label-free quantitative proteomic approaches recognize the deepest proteome coverage, ${ }^{\mathbf{1 5}, 19}$ which is advantageous for initial exploration of interesting proteins produced by ozone-treated strawberries during storage.

In this study, the protein spectrum of the strawberry fruit under different ozone treatments $(2.144,6.432$, and $10.72 \mathrm{mg}$ $\mathrm{m}^{-3}$ ) was quantitatively studied using the unlabelled proteomic method. To fully understand the regulation of protein spectra under different storage conditions, changes in fruit senescence at the proteomic level were analysed. The analysis between physiological behaviour and proteomic mechanisms are also discussed in the context of fruit senescence.

\section{Materials and methods}

\subsection{Plant materials and treatments}

Strawberries (Fragaria ananassa Duch. var. 'JingTaoXiang') were collected on March 20, 2016 in a modern agricultural science and technology innovation base in the Wuqing District, Tianjin, China. The strawberries were transported to the laboratory within $1 \mathrm{~h}$, and strawberries of uniform size, with accordant maturity, and with no pests, diseases, or mechanical damage, were selected for the experiments. Strawberries were randomly divided into four groups: three treatment groups and one control group. Every group was assigned 18 boxes, and each box weighed approximately $300 \mathrm{~g}$. Each group was placed in an ozone treatment cabinet at $0,7,14$, and 21 days with different concentrations of ozone $\left(2.144,6.432\right.$, and $\left.10.72 \mathrm{mg} \mathrm{m}^{-3}\right)$ for $10 \mathrm{~h}$ every 7 days using a precise ozone refrigerated fumigation device and then transferred to $4{ }^{\circ} \mathrm{C}$ cold storage. The ozone precision control fumigation device $(2 \mathrm{~m} \times 1.5 \mathrm{~m} \times 0.8 \mathrm{~m}$, with a storage capacity of $1200 \mathrm{~L}$ ) was developed by the National Engineering Research Center for Agricultural Products Preservation (Tianjin). Ozone was produced by a corona discharge ozone generator (3S-K10, Beijing) with production capacity of $10 \mathrm{~g} \mathrm{~h}^{-1}$ of ozone. Two ozone sensors (MIC-03, Shenzhen) were mounted on the upper and lower parts of the device and were equipped with a fan that produced a breeze of $0.2 \mathrm{~m} \mathrm{~s}^{-1}$ to $0.4 \mathrm{~m} \mathrm{~s}^{-1}$ to ensure sensitivity and uniformity of the sensor. The ozone generator, ozone sensor, and controller operate in combination to achieve a stable ozone concentration in the cold chamber. For example, the ozone concentration is set to $3 \mathrm{ppm}$ and the slewing error is $0.02 \mathrm{ppm}$. When the ozone concentration is lower than $2.99 \mathrm{ppm}$, the controller sends a signal to operate the ozone generator to generate ozone. When the ozone concentration is higher than $3.01 \mathrm{ppm}$, the controller cuts off the signal to stop the ozone generation, and therefore, the concentration of ozone in the chamber was maintained at $3 \pm$ $0.01 \mathrm{ppm}$ throughout the work period.

Three samples were obtained for each group at 7 days for the analysis of protein, and five samples (five storage points) were taken for the determination of the index.

\subsection{Physiological parameters}

2.2.1 Respiration rate. The respiration rate was detected by a GXH-3051 portable infrared analyser with a range of 0-1000 $\mu \mathrm{L} \mathrm{L}^{-1}$, produced by the Beijing Institute of Instrumentalization. The flow rate was $0.4 \mathrm{~L} \mathrm{~min}^{-1}$, and the confining time was $60 \mathrm{~min}$. The results are expressed as $\mathrm{mg} \mathrm{CO} \mathrm{CO}_{2}$ per $(\mathrm{kg} \mathrm{h})$.

2.2.2 Firmness. Strawberry fruit firmness was measured using a penetrometer (Fruit Tester) fitted with a $2 \mathrm{~mm}$ diameter flat probe, and the results are expressed as $\mathrm{kg} \mathrm{cm}^{-2}$.

2.2.3 Titratable acid. The content of titratable acid (TA) was determined by a hand-held refractometer (PAL-BX|ACID 5, Atago, Japan). The content is expressed as a percentage. ${ }^{\mathbf{2}}$

2.2.4 Anthocyanin. The analysis of anthocyanin content was performed using an ultra-performance liquid chromatography (UPLC)-based procedure, as previously described ${ }^{\mathbf{2 1 , 2 2}}$ with some modifications. A sample of anthocyanin extract $(10 \mathrm{~mL}$; methanol : acetone $:$ water $:$ formic acid $=40: 40: 20: 0.1$ ) was added to $5.0 \mathrm{~g}$ strawberry, and the mixture was thoroughly ground and exposed to ultrasonic treatment ( $35 \mathrm{kHz}$ ) for $10 \mathrm{~min}$ at $20{ }^{\circ} \mathrm{C}$. The mixture was centrifuged at $12000 \mathrm{rpm}$ at $4{ }^{\circ} \mathrm{C}$ for $20 \mathrm{~min}$. The supernatant was concentrated on a rotary evaporator at $40{ }^{\circ} \mathrm{C}$, and then dissolved in $5.0 \mathrm{~mL}$ of a duplicate solution (water : ACN : formic acid $=93: 7: 2.5$ ). Finally, the sample was filtered through $0.22 \mu \mathrm{m}$ filters and injected.

The UPLC system consisted of low temperature automatic injection, a photodiode array detector, and a chromatographic column (Waters ACQUITY UPLC BEH C18 column, $2.1 \times 50$ $\mathrm{mm}, 1.7 \mu \mathrm{m})$. The injection volume was $10 \mu \mathrm{L}$, and the flow rate was $0.4 \mathrm{~mL} \mathrm{~min}^{-1}$. Mobile phase A: $2.5 \mathrm{~mL}$ formic acid/100 $\mathrm{mL}$ water, mobile phase $\mathrm{B}$ : chromatographic grade acetonitrile (ACN). Gradient elution conditions: 0-5 min, 93-90\% A, 7-10\% B; 2 min, 90-80\% A, 10-20\% B; 12-14 $\min , 80-0 \%$ A, $20-100 \%$ B; 14-15 min, 0-93\% A, 100-7\% B; and 15-20 min, 93\% A, 7\% B. The detection wavelength was $500 \mathrm{~nm}$, and the scanning wavelength was $210-600 \mathrm{~nm}$. The column temperature was $30{ }^{\circ} \mathrm{C}$ and the sample temperature was $20{ }^{\circ} \mathrm{C}$. The content was expressed as mg P3G equivalent (C3GE)/100 $\mathrm{g}$ FW.

\subsection{Proteomic analysis}

2.3.1 Protein extraction. Approximately $1 \mathrm{~g}$ of tissue was separately ground with $\mathrm{a}-20{ }^{\circ} \mathrm{C}$ pre-cooled mortar and pestle in the presence of a urea extraction buffer $(8 \mathrm{M}$ urea, $0.5 \%$ sodium dodecyl sulphate (SDS), 1.2\% Triton X-100, $20 \mathrm{mM}$ ethylenediaminetetraacetic acid (EDTA), $20 \mathrm{mM}$ ethylene glycol tetraacetic acid (EGTA), $50 \mathrm{mM}$ sodium fluoride, 1\% glycerol 2phosphate, $1 \mathrm{mM}$ phenylmethane sulfonyl fluoride, $5 \mathrm{mM}$ dithiothreitol (DTT), $0.5 \%$ phosphatase inhibitor mixture 2 (Sigma-Aldrich), 2\% polyvinylpolypyrrolidone, and $150 \mathrm{mM}$ Tris$\mathrm{HCl}$ ( $\mathrm{pH}$ 7.6)). The specific quality data of strawberry samples is shown in Table 1 . The ratio of frozen plant powder to urea 
Table 1 Quality data for strawberry samples ${ }^{a}$

\begin{tabular}{|c|c|c|c|c|c|c|}
\hline Sample & Weight (g) & Optical density & $\begin{array}{l}\text { Protein concentration } \\
\left(\mu \mathrm{g} \mu \mathrm{L}^{-1}\right)\end{array}$ & $\begin{array}{l}\text { Total volume } \\
(\mu \mathrm{L})\end{array}$ & $\begin{array}{l}\text { Total protein } \\
(\mu g)\end{array}$ & $\begin{array}{l}\text { Volume of } \\
\text { electrophoresis }(\mu \mathrm{L})\end{array}$ \\
\hline Blank 0 & 0.8 & 1.029 & 1.76 & 150 & 264 & 14.23 \\
\hline $2.144 \mathrm{mg} \mathrm{m}^{-3}$ & 1.0 & 1.159 & 2.67 & 150 & 401 & 9.36 \\
\hline $6.432 \mathrm{mg} \mathrm{m}^{-3}$ & 0.8 & 1.023 & 1.71 & 150 & 257 & 14.61 \\
\hline $10.72 \mathrm{mg} \mathrm{m}^{-3}$ & 1.0 & 1.173 & 2.77 & 150 & 415 & 9.03 \\
\hline
\end{tabular}

extraction buffer was $1: 3(\mathrm{w} / \mathrm{v})$. Plant cell debris was removed via centrifugation at a lower speed of relative centrifugal force of $10000 \times g$ for $1 \mathrm{~h}$ at $4{ }^{\circ} \mathrm{C}$, and then a higher speed at a relative centrifugal force of $110000 \times g$ for $2 \mathrm{~h}$ at $13{ }^{\circ} \mathrm{C}$. The supernatant was mixed with three volumes of a cold acetone/methanol $12: 1$ $\mathrm{v} / \mathrm{v}$ ) organic mix for urea-methanol protein precipitation. The pellet was rinsed with 15 volumes of a cold acetone : methanol : $\mathrm{H}_{2} \mathrm{O}$ mix (12: $1: 1.4 \mathrm{v} / \mathrm{v}$ ) to remove residual pigment and urea precipitates. The pellet was air-dried and then dissolved in a resuspension buffer containing $50 \mathrm{mM}$ Tris- $\mathrm{HCl}$ (pH 6.8), 8 M urea, 5 mM DTT, 1\% SDS, and 10 mM EDTA at onethird of the original volume, and this was followed by another round of protein precipitation and resuspension. The cycle of protein precipitation and resuspension was repeated twice. ${ }^{23}$

Protein was excised from the preparative tube and mixed with $50 \mathrm{mM} \mathrm{NH}_{4} \mathrm{HCO}_{3}$ to a final concentration $0.5 \mathrm{mg} \mathrm{mL}^{-1}$. Following the addition of $100 \mathrm{mM}$ DTT to a final concentration of $10 \mathrm{mM}$, the protein fractions were mixed at $56^{\circ} \mathrm{C}$ for $60 \mathrm{~min}$, diluted $10 \times$ with $250 \mathrm{mM}$ iodoacetamide, and maintained in the dark for $60 \mathrm{~min}$. Finally, the samples were digested with trypsin (substrate to enzyme mass to mass ratio of $50: 1$ ) at $37^{\circ} \mathrm{C}$ for $12 \mathrm{~h}$. The digested supernatant fractions were stored at $-80{ }^{\circ} \mathrm{C}$ without further treatment until mass spectrometry (MS) analysis. The resulting total cellular protein was measured using a protein detergentcompatible (DC) assay (Bio-Rad) and calculated according to a bovine serum albumin (BSA) protein standard curve.

2.3.2 Liquid chromatography-tandem mass spectrometry (LC-MS/MS). The digested peptides were analysed on a QExtractive HF mass spectrometer (Thermo Scientific, Waltham, MA, USA) coupled with an Ultimate 3000 system (Thermo Scientific). The tryptic samples were resuspended with buffer A (water, $0.1 \%$ formic acid) and injected into a fused silica capillary C18 column $(3 \mu \mathrm{m}, 0.1 \times 20 \mathrm{~mm})$. The peptides were then separated with a C18 column $(120 \AA, 1.9 \mu \mathrm{m}, 1.5 \times 120 \mathrm{~mm})$ at a flow rate of $0.6 \mu \mathrm{L} \mathrm{min}{ }^{-1}$. The gradient elution profile was as follows: $6-14 \%$ buffer B ( $80 \% \mathrm{ACN}, 0.1 \%$ formic acid) for $24 \mathrm{~min}$, $14-95 \%$ B for $54 \mathrm{~min}$, and 95-96\% buffer B for $2 \mathrm{~min}^{24}$

The mass spectrometer was operated in tandem mass spectrometry (MS/MS) auto mode. Survey MS scans were acquired in the Orbitrap with the resolution set to a value of 120000 . Dynamic exclusion was set as $12 \mathrm{~s}$. Each survey scan (300-1400 $\mathrm{m} / \mathrm{z}$ ) was followed by the top 20 data-dependent MS/MS scans at a normalised scan speed of $2 \mathrm{~Hz}^{25}$

2.3.3 Protein identification and data validation. Tandem mass spectra were examined with the Mascot 2.0 search engine
(Matrix Science, London, UK) using a UniProt sequence database. ${ }^{26}$ The search results were then filtered using a cutoff of $1 \%$ for peptide false identification rate. Enzyme specificity was set as trypsin, and a maximum of two missed cleavages was allowed. Methionine oxidation and N-terminal acetylation were set as variable modifications, while carbamidomethylation of cysteine was defined as a fixed modification for database searching. A fragment mass tolerance of $0.02 \mathrm{Da}$ and a peptide mass tolerance of $10 \mathrm{ppm}$ were used for both search engines.

2.3.4 Bioinformatics analysis. We use $\mathrm{R}$ language and the Perl language program for data analysis. $\mathrm{R}$ is a free software environment for statistical computing and graphics. Raw spectrum data were processed using SEQUEST software to extract peak lists. The obtained peak lists were analyzed using Proteome Discoverer software (Thermo Scientific, version 1.4) against strawberry RNA-seq sequences combined with sequences of common contaminants, such as human keratins. The false discovery rates (FDR) were set to 0.01 . The database we searched for was a transcriptome of the strawberry fruit (the experimental material) spliced by a unigene protein sequence translated into a protein database consisting of all the plant protein blast sequence alignments in the protein database and UniProt comment information.

Using the protein extracted from the strawberry before storage as a denominator, the ratio of the normalised spectral counts from the late storage of the strawberry proteome was compared to assess differential adjustments of proteins in response to treatment. The steps of normalized spectral abundance factor (NSAF) normalization ${ }^{27}$ are as followed: the first step is to calculate the sum of all proteins in a single sample; the second step is to divide the SUM value by the largest SUM value in several samples to yield a decimal number between 0 and 1 (two reserved bits), which is the coefficient of variation; the third step is to obtain the original protein signal value, which is the deviation coefficient for each protein sample. Using a 2-fold change (FC) and $p$-values $<0.05$ as the variance for an up- or downshift in abundance, $\mathrm{FC} \geq 2$ and $p<0.05$ were considered to reflect upregulation, while $\mathrm{FC} \leq 0.5$ and $p<0.05$ were considered to reflect downregulation.

\subsection{RNA extraction and quantitative reverse transcription PCR (qRT-PCR) analysis}

Based on the differential expression of proteins in functional categories, 20 key proteins were selected for expression verification using qRT-PCR. Specific primers were designed using 
Primer 3.0 software (ESI Table $1 \dagger$ ). Total RNA was extracted from three independent samples using the MiniBEST Plant RNA Extraction Kit (TAKARA, Japan). The relative quantification of candidate genes by qRT-PCR was carried out using an ABI StepOnePlus Real-Time PCR System, and analyzed using the comparative $\mathrm{Ct}$ method with 18S rRNA (GenBank No. LOC101312917) as the internal control. The reaction was carried out using TransScript ${ }^{\circledR}$ Green Two-Step qRT-PCR SuperMix (Thermo) following the manufacturer's instructions, and three repetitions were performed. Equation $2^{-\Delta \Delta C_{t}}$ was used to calculate relative transcription levels. ${ }^{28}$

\subsection{Statistical analysis}

All experiments were conducted with three technical replicates and three biological replicates. The data were analyzed using analyses of variance (ANOVA) with SAS statistical software. The least significant difference (LSD) was calculated to determine significant differences at the 5\% level. Bioinformatics analysis was carried out to categorise proteins based on biological processes, cellular components, and molecular functions using annotations in the Protein Analysis Through Evolutionary Relationships (PANTHER) database v6.1 (http:// www.pantherdb.org), which is in compliance with gene ontology (GO) standards. Signalling pathway analysis was performed with the tools in the Kyoto Encyclopaedia of Genes and Genome database (http://www.genome.jp/kegg/pathway.html). Clusters of Orthologous Groups (COGS) category assignment was performed using the local alignment tool BLASTP with an $e$ value cutoff of $<104$. Hierarchical clustering analysis was performed with Mev 4.9 software.

\section{Results}

\subsection{Physiological quality traits}

To compare the proteomics profile with the changes in the physiological characteristics of strawberries that correspond to the different ozone treatments (as opposed to the blank treatment), fruit respiration rate, firmness, TA, and anthocyanin were measured (Fig. 1-4).

3.1.1 Respiration rate. The initial value of the strawberry respiration rate was $6.40 \mathrm{mg} \mathrm{CO}_{2}$ per $(\mathrm{kg} \mathrm{h})$ at room temperature $\left(20-25{ }^{\circ} \mathrm{C}\right)$ and was rapidly reduced after being transferred to $4{ }^{\circ} \mathrm{C}$ cold storage. At 7 days, the respiration rate of the $10.72 \mathrm{mg}$ $\mathrm{m}^{-3}$ ozone treatment group was $2.33 \mathrm{mg} \mathrm{CO}$ per $(\mathrm{kg} \mathrm{h})$, which was $63.61 \%$ lower than that of the initial value, and significantly lower than the blank and the 2.144 and $6.432 \mathrm{mg} \mathrm{m}^{-3}$ treatment groups $(p<0.05)$. However, there was no significant difference in the respiration rate between the 2.144 or $6.432 \mathrm{mg} \mathrm{m}^{-3}$ ozone treatment and the blank group $(p>0.05)$. After 7 days, the respiratory rate of each group showed a downward trend and reached the lowest value of the storage period on the 21st day. There was no significant difference $(p>0.05)$ between the respiratory rate of each treatment group at that time. After 21 days, the respiratory rate slightly increased. From the perspective of the entire storage period, only the $10.72 \mathrm{mg} \mathrm{m}^{-3}$

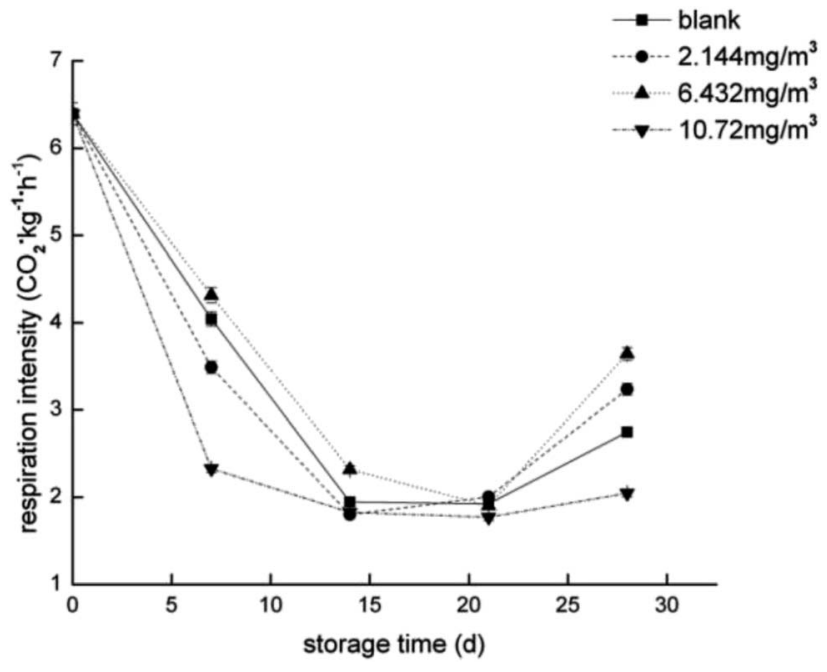

Fig. 1 Respiration rate of the strawberry fruits during storage while undergoing the four ozone treatments.

treatment group exhibited a lower respiratory rate than the blank group.

3.1.2 Firmness. The firmness of strawberries decreased with prolongation of the storage period, and the fruit in the ozone treatment group was harder than that of the blank group. The firmness of the fruit treated with $2.144 \mathrm{mg} \mathrm{m}^{-3}$ ozone was $0.1323 \mathrm{~kg} \mathrm{~cm}^{-2}$, which was $3.29 \%$ lower than that at the beginning of storage. The hardness of the 6.432 and $10.72 \mathrm{mg}$ $\mathrm{m}^{-3}$ treatment and the blank treatment groups at day 7 were $0.1231,0.1170$, and $0.1098 \mathrm{~kg} \mathrm{~cm}^{-2}$, which decreased by $10.05 \%, 14.49 \%$, and $19.73 \%$, respectively, compared with day 0 . The difference between the four treatment groups was significant $(p<0.05)$. At $14 \mathrm{~d}$, there was no significant difference in hardness between the $10.72 \mathrm{mg} \mathrm{m}^{-3}$ and $6.432 \mathrm{mg} \mathrm{m}^{-3}$ treatment groups, but the hardness of the ozone treatment group was significantly higher than that of the blank group ( $p<$ $0.05)$. At $28 \mathrm{~d}$, the hardness of the four groups was approximately $0.08 \mathrm{~kg} \mathrm{~cm}^{-2}$. Overall, ozone treatment slowed the

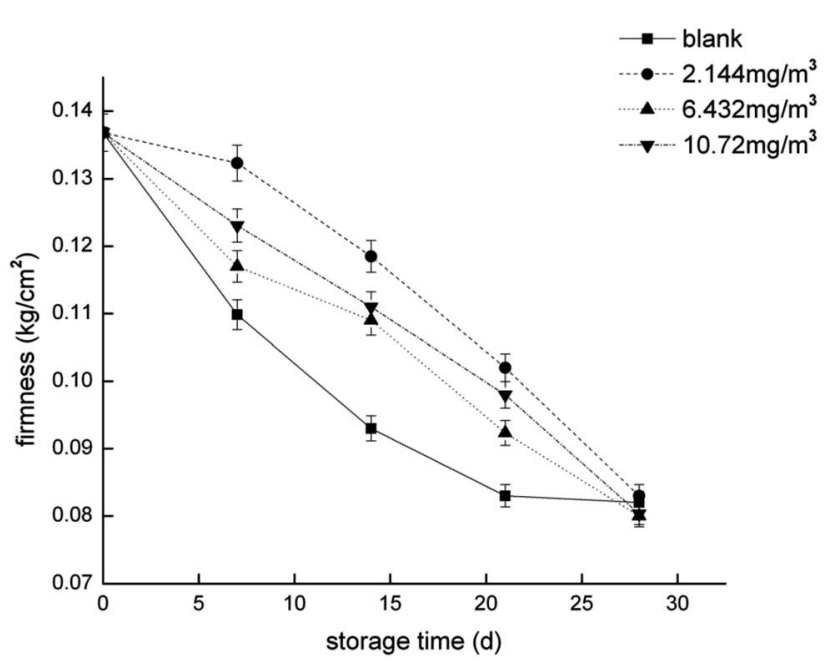

Fig. 2 Firmness of the strawberry fruits during storage while undergoing the four ozone treatments. 


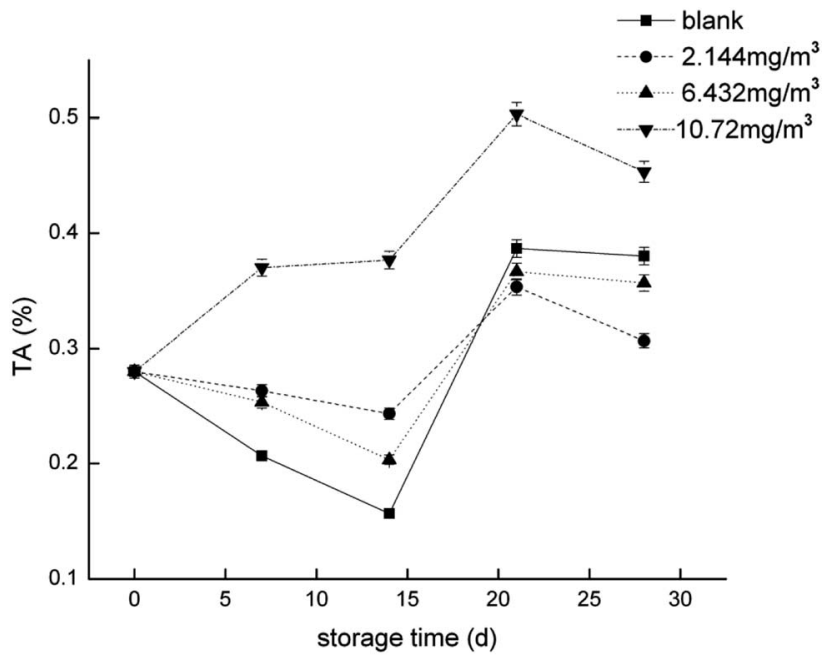

Fig. 3 Titratable acid (TA) of the strawberry fruits during storage while undergoing the four ozone treatments.

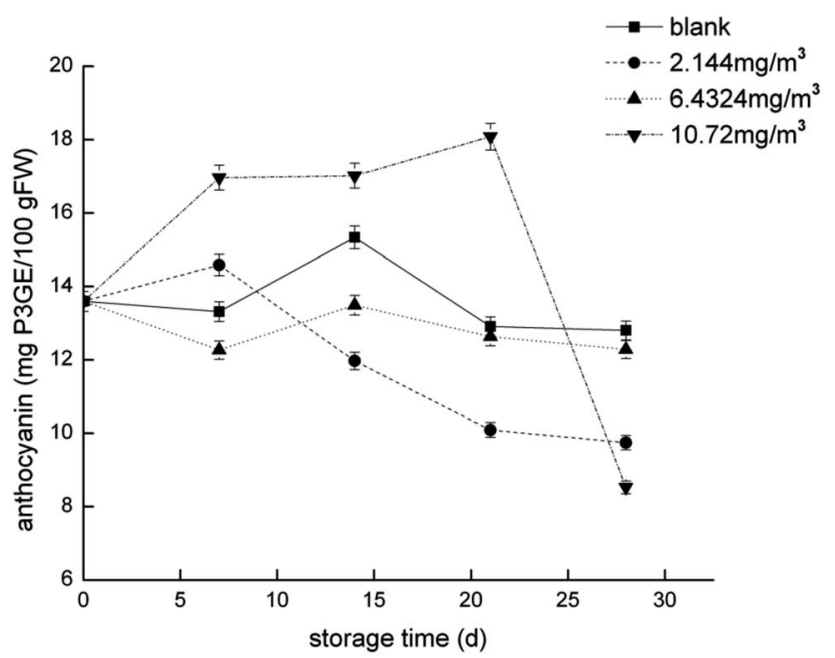

Fig. 4 Anthocyanin content of the strawberry fruits during storage while undergoing the four ozone treatments.

decline in strawberry hardness during the 28 day storage period, with the $2.144 \mathrm{mg} \mathrm{m}^{-3}$ treatment being the most effective.

3.1.3 Titratable acid (TA). The content of TA in strawberry fruit initially increased and then decreased with the prolongation of storage time. At 14 days, the TA content of the ozone treatment group was significantly higher than that of the blank group $(p<0.05)$. At $21 \mathrm{~d}$, the TA content of each treatment group reached the peak, $0.50 \%\left(10.72 \mathrm{mg} \mathrm{m}^{-3}\right), 0.38 \%$ (blank), $0.37 \%$ $\left(6.432 \mathrm{mg} \mathrm{m}^{-3}\right)$, and $0.35 \%\left(2.144 \mathrm{mg} \mathrm{m}^{-3}\right)$, which increased by $78.57 \%, 35.71 \%, 32.14 \%$, and $25 \%$, respectively, compared with the initial time, of which the TA content in the $10.72 \mathrm{mg} \mathrm{m}^{-3}$ treatment group was significantly higher than that in the other treatment groups $(p<0.05)$. However, there was no significant difference between the $2.144 \mathrm{mg} \mathrm{m}^{-3}$ treatment group, the $6.432 \mathrm{mg} \mathrm{m}^{-3}$ treatment group, and the blank group $(p>0.05)$. After 21 days, the TA content in the blank group was significantly higher than that in the $6.432 \mathrm{mg} \mathrm{m}^{-3}$ and $2.144 \mathrm{mg} \mathrm{m}^{-3}$
Table 2 The results of differential proteins at day $7^{a}$

\begin{tabular}{llll}
\hline Groups & A and B common & A up & A down \\
\hline $2.144 \mathrm{mg} \mathrm{m}^{-3}$ vs. blank 0 & 3020 & 61 & 212 \\
$6.432 \mathrm{~m} \mathrm{~m}^{-3}$ vs. blank 0 & 2954 & 37 & 297 \\
$10.72 \mathrm{mg} \mathrm{m}^{-3}$ vs. blank 0 & 3163 & 68 & 137 \\
Blank 7 vs. blank 0 & 3184 & 73 & 103
\end{tabular}

${ }^{a} \mathrm{~A}$ and $\mathrm{B}$ denote the number of proteins identified in group $\mathrm{A}$ and group $B$; A up denotes that the number of proteins upregulated in group A was higher than that in group B. A down denotes that the number of proteins downregulated in group A was lower than that in group B.

treatment groups $(p<0.05)$. However, the TA content of the $10.72 \mathrm{mg} \mathrm{m}^{-3}$ treatment group was still significantly higher than that of the blank group ( $p<0.05)$, even at the end of storage $(0.45 \%)$, and was still higher than the maximum value of the blank group.

3.1.4 Anthocyanin. The content of anthocyanins first increased and then decreased during storage time, but the peak time of different treatment groups was different. At $14 \mathrm{~d}$, the anthocyanin content of the blank group and the $6.432 \mathrm{mg} \mathrm{m}^{-3}$ treatment group reached a peak of $15.34 \mathrm{mg}$ P3GE per $\mathrm{g} F W$ and $13.49 \mathrm{mg}$ P3GE per $\mathrm{g} F W$, respectively. The peak of the $2.144 \mathrm{mg}$ $\mathrm{m}^{-3}$ treatment group appeared on day 7 at $14.58 \mathrm{mg}$ P3GE per $\mathrm{g}$ $\mathrm{FW}$, which was $6.77 \%$ higher than at the beginning of storage. However, the peak appearance time of the $10.72 \mathrm{mg} \mathrm{m}^{-3}$ treatment group was extended to the 21st day (18.08 mg P3GE per $\mathrm{g}$ FW), which was $24.82 \%$ higher than that of the initial time. The $10.72 \mathrm{mg} \mathrm{m}^{-3}$ treatment group was significantly higher than the other groups during the first 21 days of storage $(p<0.05)$. However, after the 21st day, the anthocyanin content of the $10.72 \mathrm{mg} \mathrm{m}^{-3}$ treatment group rapidly decreased to 8.52 P3GE per $\mathrm{g}$ FW within 7 days, which was less than that of any other treatment group.

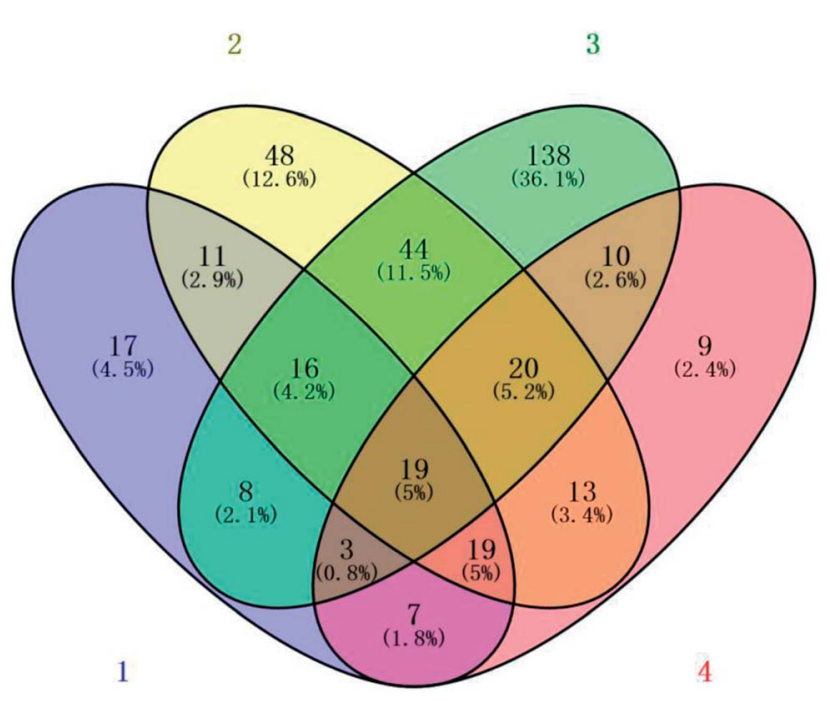

Fig. 5 Venn diagram of the number of different proteins identified in the strawberry fruit proteome after 7 days of storage in the (1) blank, (2) $2.144 \mathrm{mg} \mathrm{m}^{-3}$, (3) $6.432 \mathrm{mg} \mathrm{m}^{-3}$, and (4) $10.72 \mathrm{mg} \mathrm{m}^{-3}$ ozone treatments. 


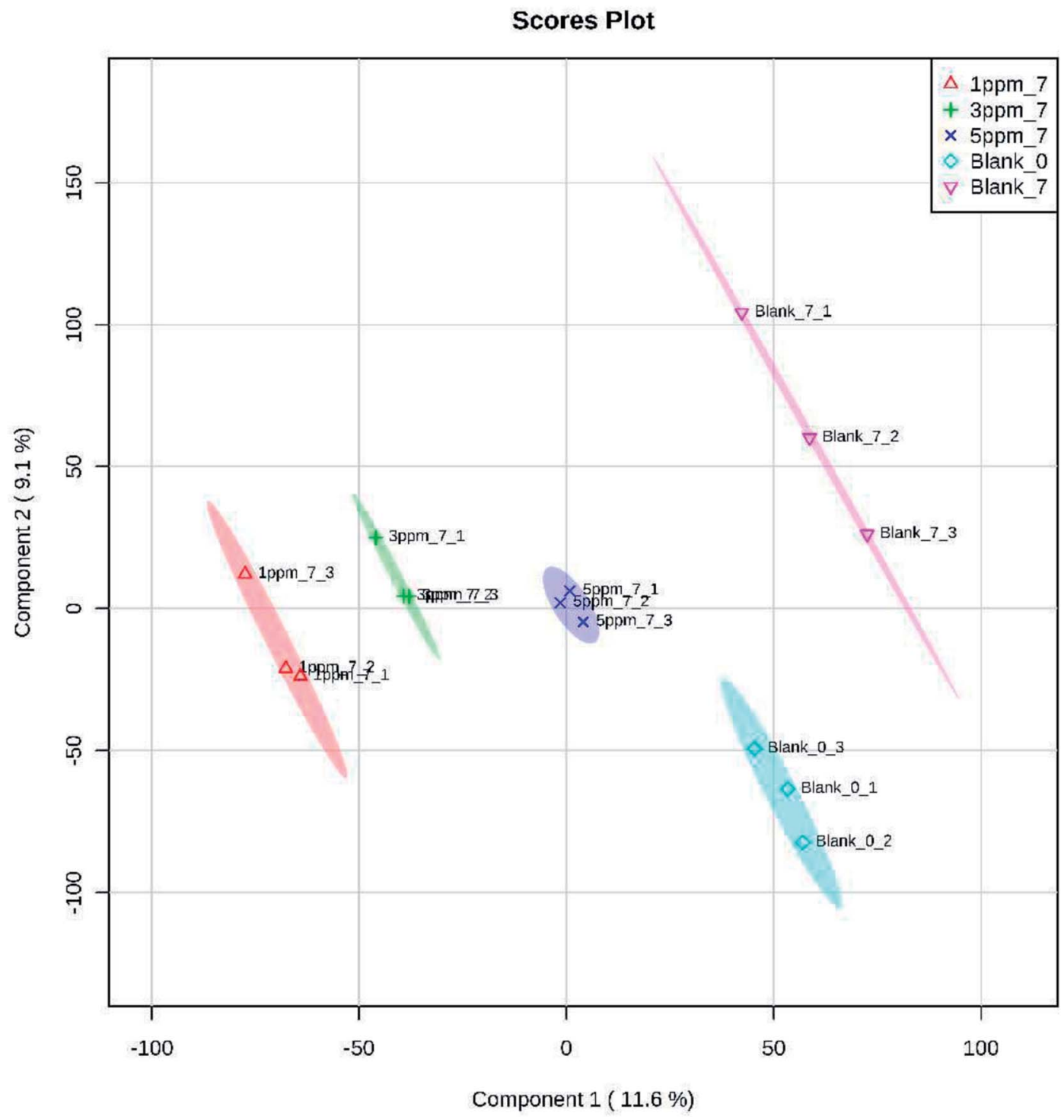

Fig. 6 PCA analysis of 382 proteins identified in the strawberries after 7 days of storage while undergoing the four ozone treatments. Notes: blank 0 is the initial time, and blank 7 is the control group at day 7; ozone treatments were administered at $2.144 \mathrm{mg} \mathrm{m}^{-3}, 6.432 \mathrm{mg} \mathrm{m}^{-3}$, and $10.72 \mathrm{mg} \mathrm{m}^{-3}$.

\subsection{Protein identification and quantification}

The result of protein identification and results of differential proteins are shown in Table 2 and Fig. 6-10.

Compared with the initial levels, 382 proteins were determined to be significantly different, and the results used in this study are shown in detail in ESI Table 2. $\uparrow$ The expression of 9 proteins was reduced, and only 1 protein was abundant in all four treatments compared with initial levels. Furthermore, compared with the initial levels, there were 18 elevated and 240 reduced proteins in the $6.432 \mathrm{mg} \mathrm{m}^{-3}$ treatment group; 48 elevated and 152 reduced proteins in the $2.144 \mathrm{mg} \mathrm{m}^{-3}$ treatment group; 37 elevated and 63 reduced proteins in the $10.72 \mathrm{mg} \mathrm{m}^{-3}$ treatment group; and 56 elevated and 44 reduced proteins in the blank treatment group. Overall, protein expression showed a downward trend under ozone treatment.
Fig. 5 compares the changes in protein expression under the different treatments at day 7. Compared with the initial levels, the expression of 77 and 13 proteins was significantly reduced and elevated, respectively, following the $2.144 \mathrm{mg} \mathrm{m}^{-3}$ ozone treatment; the abundance of 141 and 13 proteins was significantly lessened and increased, respectively, following the $6.432 \mathrm{mg} \mathrm{m}^{-3}$ treatment; and the abundance of 19 and 13 proteins was significantly lessened and elevated, respectively, following the $10.72 \mathrm{mg} \mathrm{m}^{-3}$ treatment.

Principal component analysis (PCA) is an unsupervised method of data analysis. As can be seen from Fig. 6, there is no significant difference within each treatment group, but the difference between the groups is significant. Among them, blank 0 and blank 7 were separated, indicating that the protein spectrum significantly changed after 7 days of storage. The protein profiles of the treatment groups exposed to different 


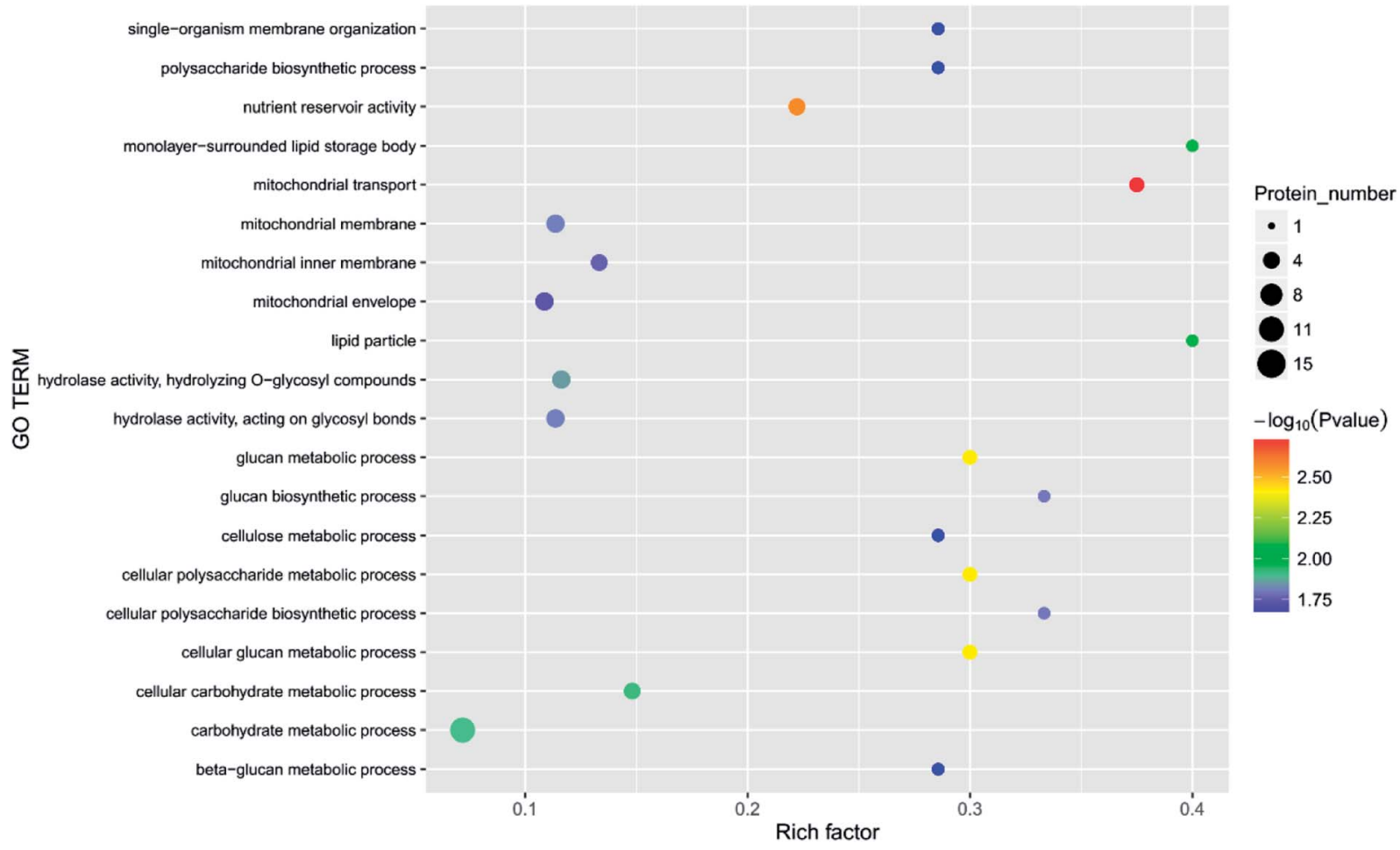

Fig. 7 Function of the main differential proteins after 7 days of storage in the blank treatment compared with initial levels.

concentrations of ozone gradually separated on the first principal component. Compared to the $6.432 \mathrm{mg} \mathrm{m}^{-3}$ and $2.144 \mathrm{mg}$ $\mathrm{m}^{-3}$ ozone treatment, the $10.72 \mathrm{mg} \mathrm{m}^{-3}$ treatment had a more pronounced tendency to approach the blank. Additionally, Fig. 7-10 show that distinct changes in protein abundance in the blank group were related to energy metabolism, anthocyanin synthesis, and cellulase metabolism. Significant changes in the $2.144 \mathrm{mg} \mathrm{m}^{-3}$ treatment group were associated with energy metabolism, folic acid synthesis, and amino acid metabolism, while the significant changes in the $6.432 \mathrm{mg}$

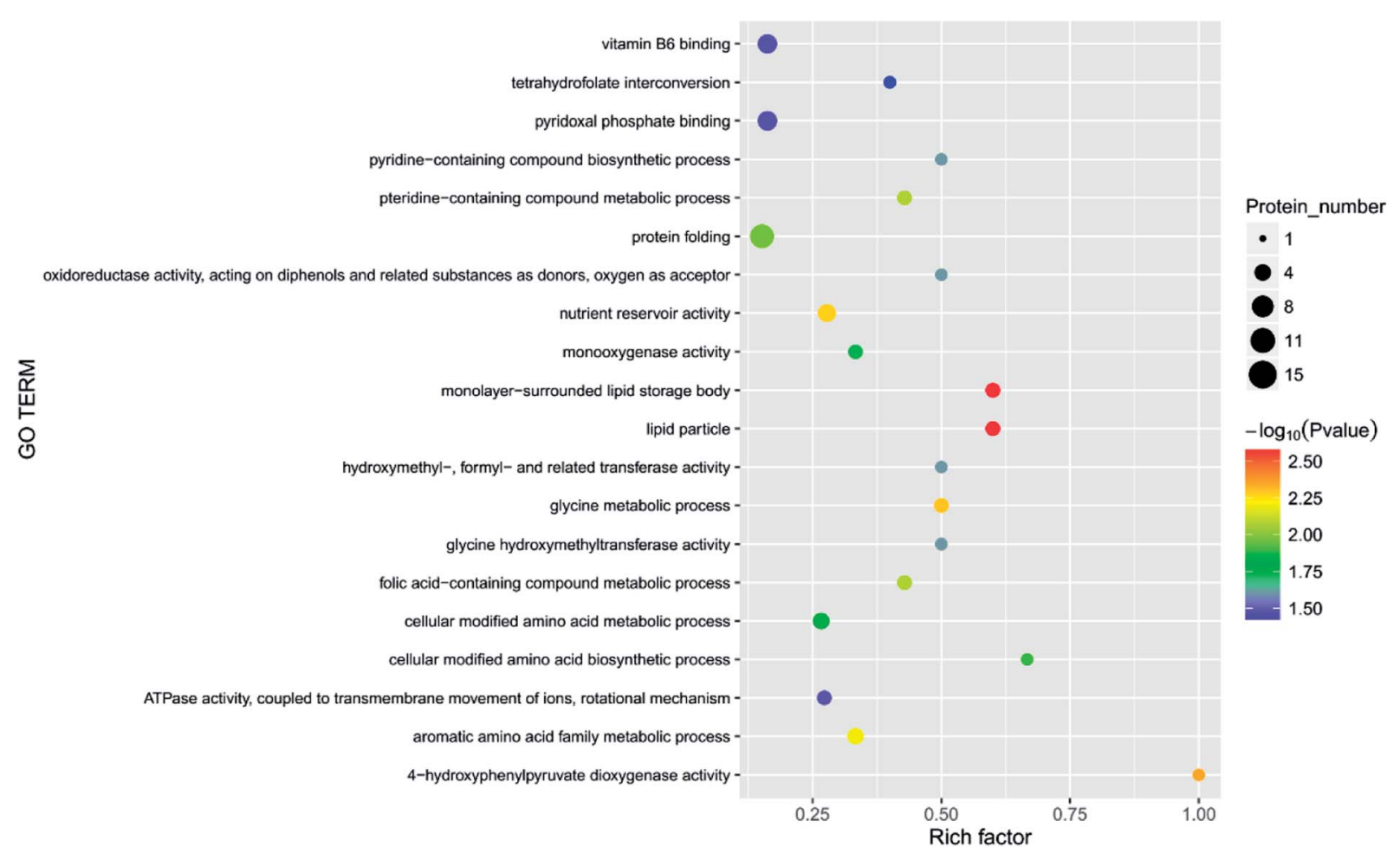

Fig. 8 Function of the main differential proteins after 7 days of storage in the $2.144 \mathrm{mg} \mathrm{m}^{-3}$ treatment compared with initial levels. 


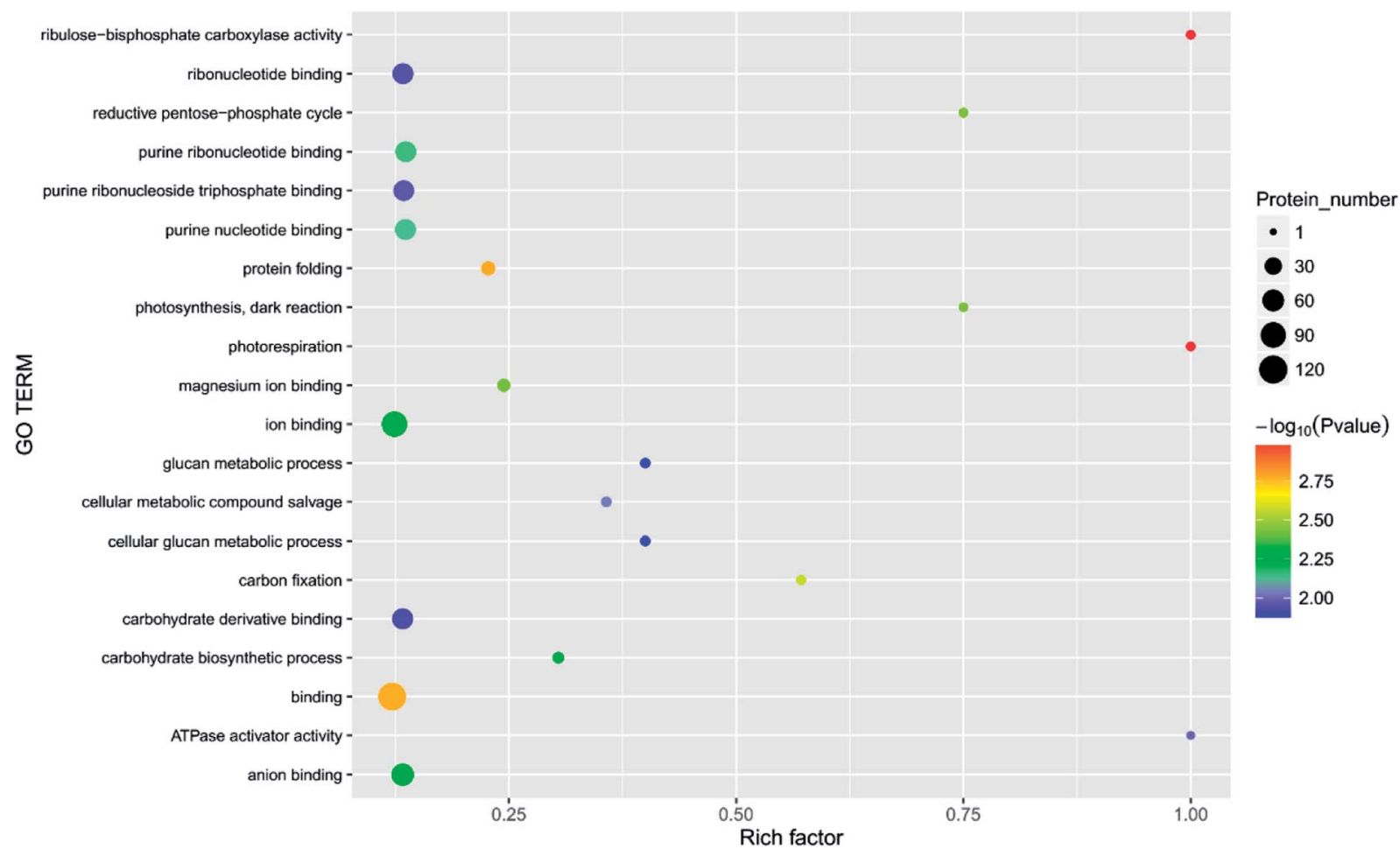

Fig. 9 Function of the main differential proteins after 7 days of storage in the $6.432 \mathrm{mg} \mathrm{m}^{-3}$ treatment compared with initial levels.

$\mathrm{m}^{-3}$ group were associated with energy metabolism, ion binding, and carbon fixation. Significant changes in the $10.72 \mathrm{mg} \mathrm{m}^{-3}$ group were related to lipid and ATP biosynthesis compared with the initial protein content.
Twenty key proteins, including three upregulated proteins (DN40398_c1_g3_i1; DN33354_c0_g1_i1 and DN38781_c0_g2_i1), two downregulated proteins (DN33938_c0_g1_i3 and DN13670_c0_g1_i1), and 15 unaltered

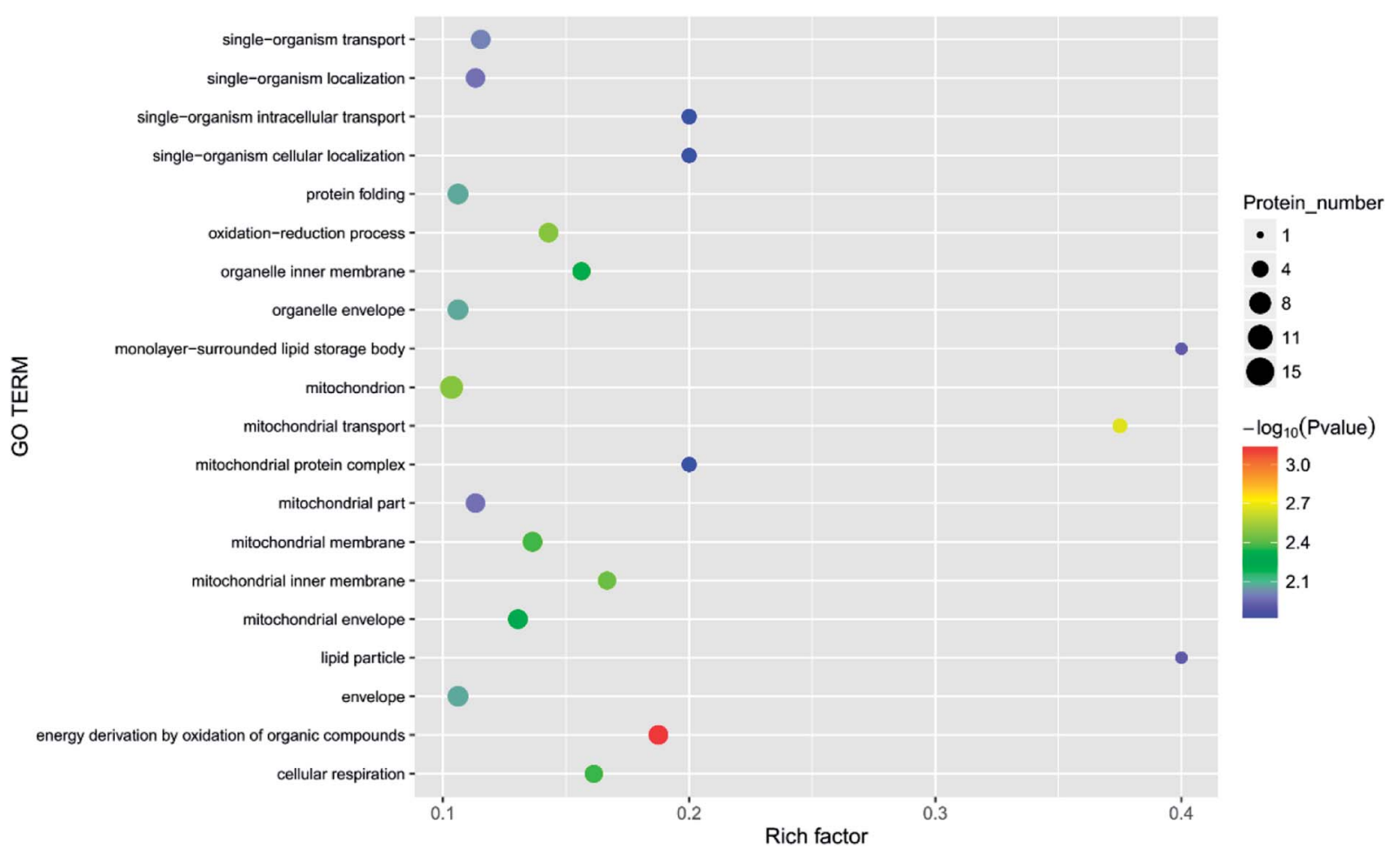

Fig. 10 Function of the main differential proteins after 7 days of storage in the $6.432 \mathrm{mg} \mathrm{m}^{-3}$ treatment compared with initial levels. 
proteins (DN38542_c1_g6_i1; DN36953_c0_g2_i1; DN38314_c1_g3_i4; DN39221_c0_g1_i3; DN35844_c0_g5_i2; DN33265_c0_g4_i1; DN46943_c0_g1_i1; DN35749_c0_g2_i4; DN39915_c0_g1_i3; DN32133_c0_g1_i1; DN37718_c0_g2_i3; DN40671_c0_g1_i8; DN36541_c0_g1_i1; DN41597_c1_g1_i1; and DN41597_c1_g1_i8) were selected using qRT-PCR to investigate the expression changes at the RNA level. The results indicated that the transcriptional expression patterns of the 20 genes (1.3-fold) were consistent with their protein expression models, because the FCs of proteins 4 and 6 are approximately 1.7 and 0.5 , respectively, in the 10.72 ozone treatment group at day 7 compared with blank 0 .

\section{Discussion}

Strawberry is one of the most popular fruit crops in the world and is recognised for its nutrition and flavour. Post-harvest storage conditions play a key role in fruit quality, which is influenced by sugar, acid, volatile compounds, and different combinations of colours and flavours. ${ }^{29}$ Many physiological processes respond to environmental stimuli during storage, and some processes independently adjust the basic post-harvest response (Fig. 11).

\subsection{Physiological trait analysis}

4.1.1 Respiration. Among the three treatment concentrations, $10.72 \mathrm{mg} \mathrm{m}^{-3}$ ozone had the most obvious inhibitory effect on strawberry respiration. First, an increasing number of studies have shown that non-respiratory climacteric fruits are also regulated by ethylene, and ethylene scavenging can reduce the physiological and biochemical changes associated with strawberry maturation. ${ }^{30}$ The negative oxygen ions produced by

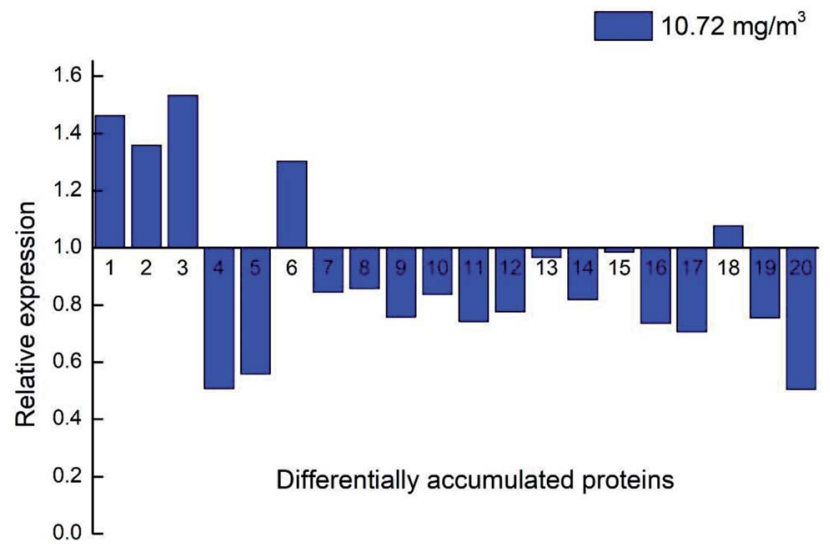

Fig. 11 Expression profiles of the 20 genes via qRT-PCR. Note: $10.72 \mathrm{mg} \mathrm{m}^{-3}$ at day 7 was compared with blank 0 . (1) DN40398_c1_g3_i1; (2) DN33354_c0_g1_i1; (3) DN38781_c0_g2_i1; (4) DN33938_c0_g1_i3; (5) DN13670_c0_g1_i1; (6) DN38542_c1_g6_i1; (7) DN36953_c0_g2_i1; (8) DN38314_c1_g3_i4; (9) DN39221 $\mathrm{c0}$ g1 i3. (10) DN35844 c0 g5 i2 - (11) DN33265_c0_g4_i1; (12) DN35749_c0_g2_i4; (14) DN32133_c0_g1_i1; $\quad$ (16) DN40671_c0_g1_i8; (18) DN41597_c1_g1_i1; (20) DN41597_c1_g1_i8. ozone have strong penetrating power, and could enter the strawberry cells to neutralize charge and decompose the ethylene, ethanol, acetaldehyde, and other gases released by the strawberry during the mature aging process. In addition, treatment with a higher concentration of ozone has a stronger scavenging effect, which slows down the metabolism of the fruit. Second, $10.72 \mathrm{mg} \mathrm{m}^{-3}$ ozone treatment can promote the shrinkage of stomatal surfaces on strawberries. ${ }^{31}$ The stoma is the main organ of plants for respiration and transpiration. The size and number of stomata directly affect the strength of plant respiration.

4.1.2 Firmness. Ozone treatment inhibited the decline in strawberry hardness during the 28 day storage period, with the $2.144 \mathrm{mg} \mathrm{m}^{-3}$ treatment being the most effective, followed by $10.72 \mathrm{mg} \mathrm{m}^{-3}$. This is consistent with the conclusions obtained by Han. ${ }^{32}$ It was found that the hardness of mulberry in the blank group gradually decreased with the prolongation of storage time, but the pre-cooling combined with $4.288 \mathrm{mg} \mathrm{m}^{-3}$ ozone treatment reduced the hardness of black mulberry after a small increase in the first 3 days of storage. It was found by scanning electron microscopy that ozone treatment can inhibit the degradation of epidermal tissue of black mulberry and maintain the morphological characteristics of the cells. The dense epidermal structure can inhibit the evaporation of water and the invasion of bacteria. ${ }^{32}$ Aday $^{33}$ found that the hardness of strawberries treated with $0.075 \mathrm{mg} \mathrm{L}^{-1}$ ozone water was higher than that of the blank group. There was no significant difference in the effect of $0.075 \mathrm{mg} \mathrm{L}^{-1}$ ozone water and $30 \mathrm{~W}$ sonication on strawberry hardness $(p>0.05)$. Glowacz ${ }^{34}$ found that $100 \mu \mathrm{mol} \mathrm{mol}^{-1}$ ozone treatment did not significantly affect the hardness of red pepper $(p>0.05)$, but it caused the hardness of zucchini to be significantly lower than that of the blank $(p<$ $0.05)$.

4.1.3 TA. The content of TA in postharvest strawberry also exhibited transformation and balance. Studies have shown that TA is a direct substrate for respiration, and inhibition of respiratory metabolism leads to an increase in TA content. ${ }^{35}$ The effect of ozone treatment on the TA content of strawberries greatly varied. The titratable acid content remained the highest in the $10.72 \mathrm{mg} \mathrm{m}^{-3}$ ozone treatment group compared to the others throughout the storage time, perhaps because the $10.72 \mathrm{mg} \mathrm{m}^{-3}$ treatment group has the lowest respiratory rate and reduces the consumption of TA as a respiratory matrix of glycolysis and the tricarboxylic acid (TCA) cycle. However, it may be that a high concentration of ozone inhibits TA from participating in the synthesis of phenols, amino acids, esters, and aromatics, while the $2.144 \mathrm{mg} \mathrm{m}^{-3}$ and $3 \mathrm{mg} \mathrm{m}^{-3}$ ozone treatment groups showed an advantage only in the first 21 days (compared to the blank). Ali $^{36}$ also found that the decrease in the TA content in papaya was inhibited compared to the blank group and the lower ozone concentration treatment group when the ozone treatment concentration was higher than $2.5 \mathrm{ppm}$. Additionally, low concentrations of ozone did not significantly affect the TA content of tomato and citrus $(p>0.05){ }^{37}$

4.1.4 Anthocyanin. The biosynthesis of anthocyanins still continues in the harvested strawberry. ${ }^{38}$ However, anthocyanins are a reducing substance that participates in redox reactions. 
The maximum time of the anthocyanin content in strawberry fruit for each treatment group was different, which may be related to the balance of anthocyanin production and consumption. It was observed that the $10.72 \mathrm{mg} \mathrm{m}^{-3}$ ozone treatment may increase the content of anthocyanins by promoting the process of phenylpropanoid metabolism in the early stage of storage, as well as the activity and protein abundance of key enzymes, such as phenylalanine deaminase, anthene synthase, and chalcone isomerase, in the flavonoid synthesis pathway. ${ }^{39}$ However, in the later stage of storage, ozone as a strong oxidant will cause oxidative degradation of anthocyanins, and the degradation of $10.72 \mathrm{mg} \mathrm{m}^{-3}$ is most obvious.

\subsection{Proteins associated with energy metabolism}

In the current study, the physiological activities associated with carbon fixation are primarily involved in the Calvin cycle, which is a glucose generation process that occurs in plant chloroplasts. ${ }^{40}$ The most important processes in the Calvin cycle are the formation of two molecules of triphosphate glycerol under the action of enzymes such as ribulose-1,5-bisphosphate (RUBP) carboxylase, ${ }^{\mathbf{4 1}}$ and the formation of glyceraldehyde 3-phosphate under the action of hydrogenated nicotinamide adenine dinucleotide phosphate (NADP), ATP, and the reduction of enzyme. ${ }^{42,43}$ In the current study, several enzymes, such as RUBP carboxylase (DN40398_c1_g3_i1, rbcL), were significantly increased in the four treatments, suggesting that in the early stages of storage, the fruit slowly matured, and nutrients such as glucose, fatty acids, and amino acids were generated. The fruit has a tendency to increase carbon fixation by adjusting its own enzyme activity. The level of glucose-1-phosphate adenylyltransferase (DN33938_c0_g1_i3) was less abundant in the blank, 2.144, 6.432, and $10.72 \mathrm{mg} \mathrm{m}^{-3}$ treatments. The abundance of pyruvate kinase (DN36953_c0_g2_i1), nicotinatenucleotide pyrophosphorylase (carboxylating; DN38516_c1_g1_i3), chloroplastic 3-dehydroquinate synthase (DN39504_c0_g2_i1), and acyl-(acyl-carrier-protein) desaturase (DN40671_c0_g1_i8) did not significantly change between the blank and the $10.72 \mathrm{mg} \mathrm{m}^{-3}$ treatments, but were significantly less abundant in the 2.144 and $6.432 \mathrm{mg} \mathrm{m}^{-3}$ treatments. The expression of the chloroplast ATP synthase subunit alpha (DN38314_c1_g3_i4), chlorophyll $a-b$ binding protein, chloroplastic (DN37339_c1_g1_i1) did not significantly change between the blank and the 6.432 and $10.72 \mathrm{mg} \mathrm{m}^{-3}$ treatments, but were significantly lessened in the $2.144 \mathrm{mg} \mathrm{m}^{-3}$ treatment group. The expression of D-3-phosphoglycerate dehydrogenase (DN38712_c1_g3_i2), alpha-1,4 glucan phosphorylase (DN36541_c0_g1_i1), and carbamoyl phosphate synthase large chain (DN41489_c0_g5_i2) did not significantly change between the blank treatment and the 2.144 and $10.72 \mathrm{mg} \mathrm{m}^{-3}$ treatments, but were significantly reduced in the $6.432 \mathrm{mg} \mathrm{m}^{-3}$ treatment. This indicates that the dark reaction of photosynthesis in the blank and $10.72 \mathrm{mg} \mathrm{m}^{-3}$ treatments was relatively smooth and contributes to the accumulation of organic nutrients in the fruit, which is beneficial to the early storage of immature fruit.
The processes involved in the decomposition of carbohydrates are glycolysis and the TCA cycle. ${ }^{44}$ Glycolysis is the process of decomposing glucose or glycogen into pyruvic acid, ATP, and NADH. The TCA cycle is a ubiquitous metabolic pathway in aerobic organisms that occurs in mitochondria, and is the ultimate metabolic pathway and hub of three nutrients (carbohydrates, lipids, and amino acids). The TCA cycle is an extremely complex process, and the key process is divided into the following steps: acetyl CoA and oxaloacetate are condensed to form citric acid under the action of citrate synthase; citric acid is isomerised to produce isocitric acid under the action of citric acid isomerase; isocitric acid is oxidised to produce $\alpha$ ketoglutaric acid; ketoglutarate is converted to succinic acid by the action of glutaric acid decarboxylase; ${ }^{45}$ succinic acid is converted to fumaric acid by oxidative dehydrogenation; ${ }^{46}$ and finally, fumaric acid hydrolyses to produce malic acid, and malic acid is dehydrogenated to oxaloacetic acid. The process is expressed as an equation. ${ }^{\mathbf{4 4 , 4 7 , 4 8}}$

There are three key enzymes in glycolysis: hexokinase, ${ }^{49,50} 6$ phosphofructose-1-kinase and pyruvate kinase. ${ }^{47}$ Their catalytic reactions are essentially irreversible..$^{52}$ In the current study, the levels of these three enzymes in the four treatments was significantly different. There was a significant reduction of 6phosphate fructokinase-1 (DN39221_c0_g1_i3) during the $6.432 \mathrm{mg} \mathrm{m}^{-3}$ treatment. Pyruvate kinase (DN36953_c0_g2_i1, DN35844_c0_g5_i2, DN36176_c0_g1_i1) was significantly less abundant in the 2.144 and $6.432 \mathrm{mg} \mathrm{m}^{-3}$ treatments. Hexokinase (DN40359_c1_g9_i1) was also significantly lessened in the 2.144 and $6.432 \mathrm{mg} \mathrm{m}^{-3}$ treatments.

The key enzymes associated with the TCA cycle that were detected in this study are shown in the following table:

As shown in Table 3, the abundance of malate synthase (DN33354_c0_g1_i1) was increased in the four treatments. Citrate synthase (DN38781_c0_g2_i1) and isocitrate lyase were increased in the 10.72 and $6.432 \mathrm{mg} \mathrm{m}^{-3}$ treatments, respectively. However, malic enzyme (DN33265_c0_g4_i1) was less abundant in the blank and 2.144 and $6.432 \mathrm{mg} \mathrm{m}^{-3}$ treatments. The expression of succinate dehydrogenase (ubiquinone) ironsulfur subunit (DN46943_c0_g1_i1), malic enzyme (DN41132_c1_g2_i4), and pantothenate kinase (DN39070_c0_g2_i7) was less abundant in the $2.144 \mathrm{mg} \mathrm{m}^{-3}$ treatment. The abundance of proteins related to the production of pyruvate, acetoacetic acid, coenzyme A, and succinyl CoA were lessened. The amount of enzyme hydrolysed by fumaric acid was also reduced. ${ }^{53}$

The TCA cycle is the primary energy supply for the cell, but it is also the primary method of acid production in plants. ${ }^{54}$ Oxaloacetic acid is one of the limiting factors of the TCA cycle rate, ${ }^{48}$ and we found that both the 2.144 and $6.432 \mathrm{mg} \mathrm{m}^{-3}$ ozone treatments inhibited its production. This may indicate that these treatments can inhibit cell metabolism and decrease cell viability at the beginning of storage. In addition, when the direct energy material is insufficient, it is necessary for acid to be consumed. The $10.72 \mathrm{mg} \mathrm{m}^{-3}$ treatment is conducive to the formation of citric acid and other acids, which may indicate that it results in the highest content of TA of the four treatments. There was no significant difference in protein expression 
Table 3 The key enzymes associated with the tricarboxylic acid cycle ${ }^{a}$

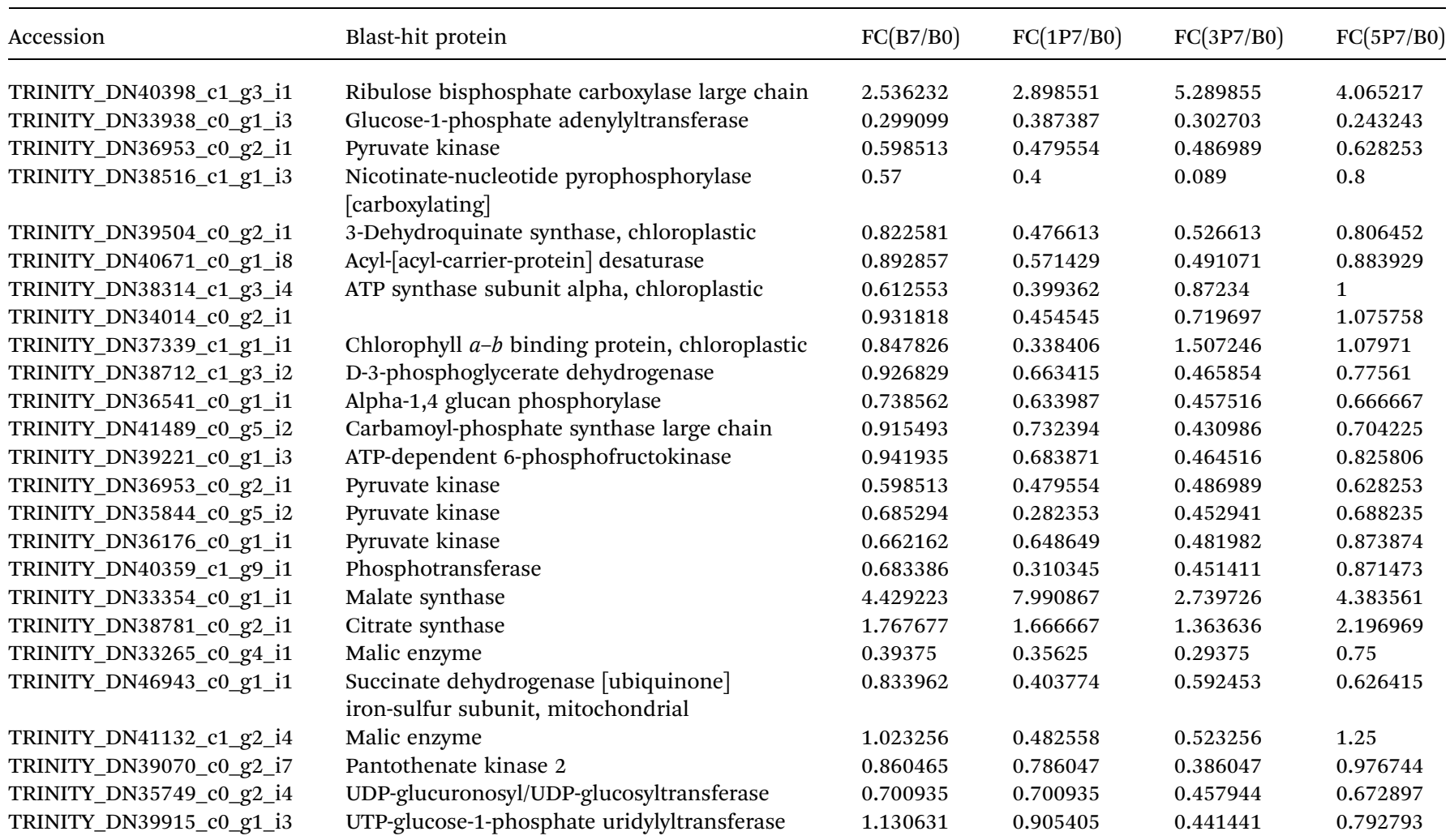

\footnotetext{
${ }^{a}$ The accession is the number of proteins, and the Blast-hit protein is the most homologous protein obtained by comparison with the nonredundant database of the National Center for Biotechnology Information (NCBI). B7, 1P7, 3P7 and 5P7 are blank, $2.144,6.432$ and 10.72 mg $\mathrm{m}^{-3}$ at day 7 respectively. $\mathrm{B} 0$ is the initial time.
}

between the blank treatment and the $10.72 \mathrm{mg} \mathrm{m}^{-3}$ treatment in the TCA cycle, in addition to the inhibition of acetoacetic acid in the blank treatment. This may result in a reduction in the efficiency of the TCA cycle while the need for energy sources is high, which may lead to the consumption of total soluble solids (TSS) and TA as energy substrates.

UDP-glucuronosyl/UDP-glucosyltransferase (DN35749_c0_g2_i4) and UTP-glucose-1-phosphate uridylyltransferase (DN39915_c0_g1_i3) are two enzymes closely related to the production of glucose, and they can promote the conversion of glucose-1-phosphate into UDP-glucose. ${ }^{55}$ The two enzymes were less abundant in the $6.432 \mathrm{mg} \mathrm{m}^{-3}$ treatment, which may be the reason that the TSS in the $6.432 \mathrm{mg} \mathrm{m}^{-3}$ treatment is lower than the blank, $2.144 \mathrm{mg} \mathrm{m}^{-3}$, and $10.72 \mathrm{mg} \mathrm{m}^{-3}$ treatments.

\subsection{Proteins associated with anthocyanin content}

Anthocyanins and flavonoids are not only two important nutrients in strawberries, but also two important indicators of the quality of strawberry storage..$^{56}$ Anthocyanins are a family of compounds that react with anthocyanidins and glucose, which are synthesised in the endoplasmic reticulum and cytoplasm, and are ultimately transported to the vacuole. Anthocyanins have antioxidant and antibacterial functions, and a subclass of flavonoids also leads to delayed senescence, and is the pigment responsible the red colour of the strawberry. Phenylalanine ammonia-lyase, chalcone synthase (CHS), chalcone isomerase, flavonoid 3-hydroxylase, dihydroflavonol reductase, anthocyanidin synthase (ANS), and anthocyanidin 3-O-glucosyltransferase play important roles in the synthesis of anthocyanins and flavonoids, and some proteins associated with transcription and the production of pigment also play a regulatory role. ${ }^{57}$ The synthesis of anthocyanins, glycosides, and flavonoids in strawberry fruit is shown in Fig. 12.

The transformation of shikimic acid into phenylalanine is not mentioned in Fig. 12. Shikimic acid is the starting material for the synthesis of anthocyanins and flavonoids. ${ }^{61}$ The amount of 3-dehydroquinate synthase (DN32133_c0_g1_i1) associated with phenylalanine synthesis was significantly reduced in the $6.432 \mathrm{mg} \mathrm{m}^{-3}$ treatment in this study. Cinnamyl-alcohol dehydrogenase isoform 3 (DN32133_c0_g1_i1) and 4-hydroxyphenylpyruvate dioxygenase (DN38542_c1_g11_i3; DN38542_c1_g6_i1), which are associated with the synthesis of coumaryl and tetraoxystyrene ketones, were significantly lessened in the 2.144 and $6.432 \mathrm{mg} \mathrm{m}^{-3}$ treatments. CHS was significantly reduced in the blank treatment, and the 2.144 and $6.432 \mathrm{mg} \mathrm{m}^{-3}$ treatments. ANS was only significantly reduced in the $6.432 \mathrm{mg} \mathrm{m}^{-3}$ treatment. In addition, cytochrome $\mathrm{P} 450$ (DN41597_c1_g1_i1; DN41597_c1_g1_i8) was less abundant in the $2.144 \mathrm{mg} \mathrm{m}^{-3}$ treatment group. The amount of calmodulinbinding transcription activators (CAMTA) domain class transcription factor (DN37953_c0_g10_i2) as a regulator protein was significantly reduced in the $6.432 \mathrm{mg} \mathrm{m}^{-3}$ treatment group, 


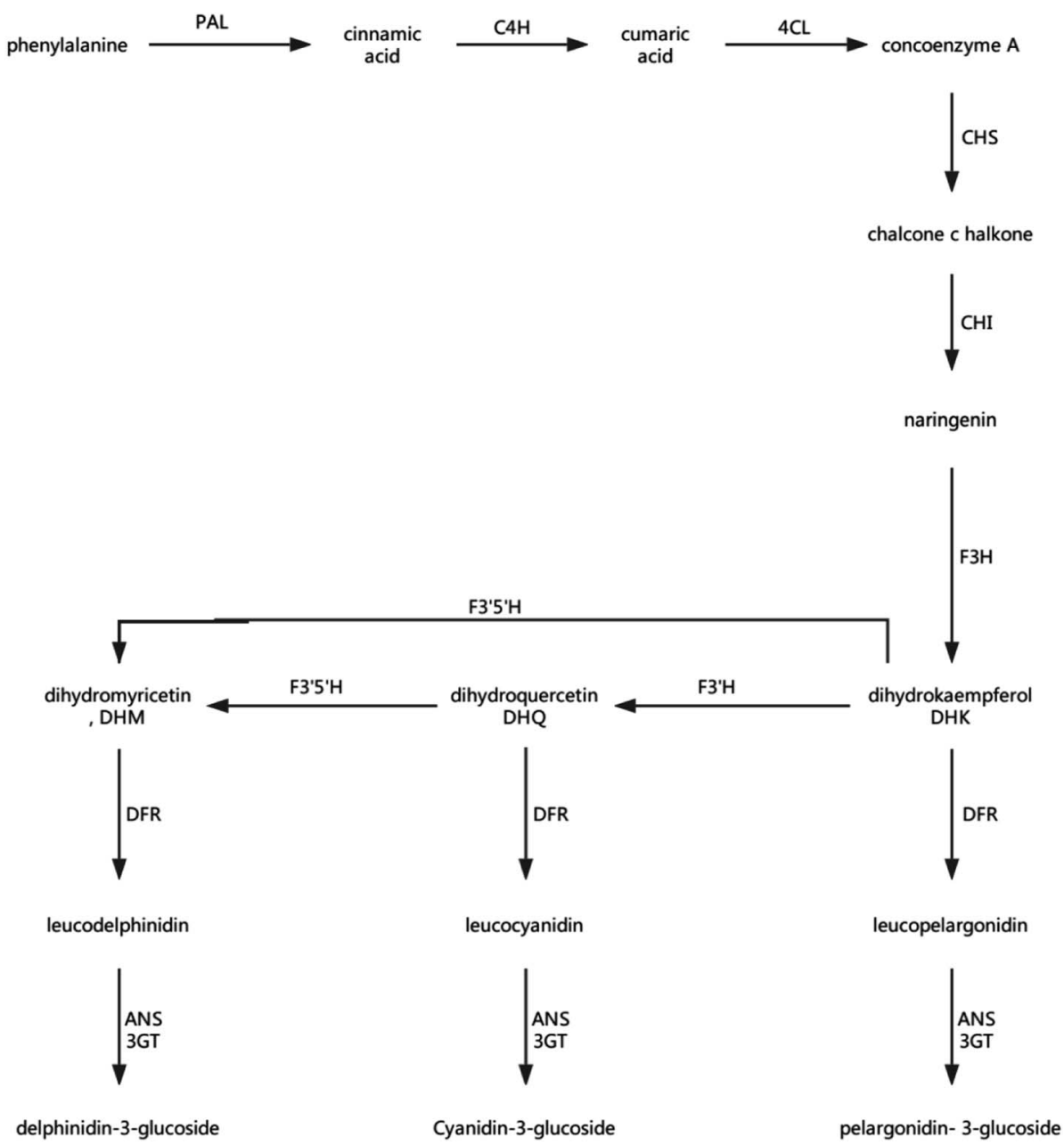

Fig. 12 Plant anthocyanin biosynthetic pathway. PAL: phenylalanine ammonia-lyase; $\mathrm{C} 4 \mathrm{H}$ : cinnamate-4-hydroxylase; 4CL: 4-coumarate: CoA ligase; CHS: chalcone synthase; ${ }^{58} \mathrm{CHI}$ : chalcone isomerase; ${ }^{59} \mathrm{F3H}$ : flavonoid 3-hydroxylase; ${ }^{60} \mathrm{~F} 3^{\prime} \mathrm{H}$ : flavonoid $3^{\prime}$-hydroxylase; ${ }^{60} \mathrm{~F} 3^{\prime} 5^{\prime} \mathrm{H}$ : flavonoid $3^{\prime}, 5^{\prime}$-hydroxylase; 60 DFR: dihydroflavonol reductase; ANS: anthocyanidin synthase; and 3GT: transketolase.

which may result in reduced glycoside binding to anthocyanidins. The regulatory changes in these enzymes may also explain the high content of anthocyanins and flavonoids in the $10.72 \mathrm{mg} \mathrm{m} \mathrm{m}^{-3}$ treatment group and the low content in the $6.432 \mathrm{mg} \mathrm{m}^{-3}$ treatment group.

\subsection{Proteins contribute to fruit firmness}

The softening of fruit becomes more obvious as the storage time increases. ${ }^{62}$ Pectinase, cellulose, and other enzymes related to glucose metabolism play a vital role in this process. ${ }^{63}$ The amount of endoglucanase (DN13670_c0_g1_i1) involved in the degradation of cellulose was significantly reduced in all four treatments, which indicated that stressful reactions that soften fruit are produced in cells. Pectinesterase (DN37718_c0_g2_i3), which slows the degradation of pectin in strawberries, was significantly less abundant in the $2.144 \mathrm{mg} \mathrm{m}^{-3}$ treatment group. The levels of the reversible glycosylated polypeptide family (DN38934_c0_g5_i4) associated with cellulose synthesis were significantly reduced in the blank and $6.432 \mathrm{mg} \mathrm{m}^{-3}$ treatments, which reduced the synthesis of cellulose at the beginning of storage and resulted in insufficient levels of cellulose combined with pectin.

Overall, the physiological indicators of strawberries exhibited detailed changes from ozone treatment. Although lowconcentration ozone $\left(2.144 \mathrm{mg} \mathrm{m}^{-3}\right.$ and $\left.6.432 \mathrm{mg} \mathrm{m}^{-3}\right)$ resulted in maintaining the firmness of the strawberries compared with the control group, it was not conducive to the accumulation and maintenance of TA and anthocyanins, and the inhibition of respiration was not obvious. However, the respiration of strawberry was thoroughly inhibited in the highconcentration ozone treatment group $\left(10.72 \mathrm{mg} \mathrm{m}^{-3}\right)$, which promoted the accumulation of TA and anthocyanin in the strawberries, and maintained the firmness. For the storage of post-harvest strawberries, $10.72 \mathrm{mg} \mathrm{m}^{-3}$ ozone is more suitable because low concentrations of ozone can cause damage to strawberry fruits, resulting in some unfavorable inducing factors. ${ }^{64}$

At the same time, enzymes associated with energy metabolism, fruit firmness, and anthocyanin synthesis were detected and found to be different after proteomic analysis between the ozone treatment groups and the control group. The enzyme associated with the promotion of fruit firmness increased in the 
ozone treatment groups, which explains that it was the ozone that promoted the maintenance of strawberry firmness. The enzymes associated with the TCA cycle, Calvin cycle, and anthocyanin synthesis were markedly decreased in the lowconcentration ozone treatment group, which also explained the decrease in the accumulation of TA and anthocyanin, while the energy metabolism-related enzyme remained essentially unchanged in the $10.72 \mathrm{mg} \mathrm{m}^{-3}$ treatment group. In addition to citric acid and malate synthase, the enzyme associated with anthocyanin synthesis increased in the $10.72 \mathrm{mg} \mathrm{m}^{-3}$ treatment group, which may be the reason for the increase in the cumulative amounts of anthocyanins and TA.

\section{Conflicts of interest}

The authors declare that there are no competing financial interests.

\section{Acknowledgements}

This work was supported by the Special Fund for the National Natural Science Foundation of China (31501547); the Innovation Team of the Tianjin Forestry \& Pomology Research System (ITTFPRS2018009); the National Key R\&D Program of China (2016YFD000903); the Tianjin Youth Fund Project (16JCQNJC14800); the Provincial Natural Science Foundation of Zhejiang (LY17C200008 \& LY17C200014); the Provincial Public Welfare Technology Research Project of Zhejiang (LGN18C200022); and the Opening Fund of Provincial Key Laboratory (2016KF0015).

\section{References}

1 J. G. Kim, A. E. Yousef and M. A. Khadre, Adv. Food Nutr. Res., 2003, 45(03), 167-218.

2 I. S. Minas, G. S. Karaoglanidis, G. A. Manganaris and M. Vasilakakis, Postharvest Biol. Technol., 2010, 58(3), 203210.

3 X. Chen, Y. Zhu, Z. Wang, H. Zhu, Q. Pan and S. Su, J. Proteomics, 2016, 136, 13-24.

4 J. M. Palma, F. J. Corpas and L. A. del Río, J. Proteomics, 2011, 74(8), 1230-1243.

5 S. Baginsky, L. Hennig, P. Zimmermann, W. Gruissem, J. Joyard and S. Mccormick, Plant Physiol., 2010, 152(2), 402-410.

6 J. Labaer, Genet. Med., 2002, 4(6 suppl.), 2S-9S.

7 A. Molassiotis, G. Tanou, P. Filippou and V. Fotopoulos, Proteomics, 2013, 13(12-13), 1871-1884.

8 L. Li, Z. Luo, X. Huang, L. Zhang, P. Zhao and H. Ma, J. Proteomics, 2015, 120, 44-57.

9 R. Pedreschi, M. Hertog, J. Robben, K. S. Lilley, N. A. Karp and G. Baggerman, J. Agric. Food Chem., 2009, 57(15), 6997-7004.

10 M. J. Martínezesteso, S. Sellésmarchart, D. Lijavetzky, M. A. Pedreño and R. Brumartínez, J. Exp. Bot., 2011, 62(8), 2521.
11 R. Nilo, C. Saffie, K. Lilley, R. Baeza-Yates, V. Cambiazo, R. Campos-Vargas, M. González, L. A. Meisel, J. Retamales, H. Silva and A. Orellana, BMC Genomics, 2010, 11, 43.

12 G. Koehler, S. K. Randall, P. Winge, J. Rohloff, R. C. Wilson and M. Alsheikh, Acta Hortic., 2012a, 929, 73-80.

13 G. Tanou, I. S. Minas, E. Karagiannis, D. Tsikou, S. Audebert, K. K. Papadopoulou, et al., Ann. Bot., 2015, 116(4), 649.

14 N. Tzortzakis, T. Taybi, E. Antony, I. Singleton, A. Borland and J. Barnes, Postharvest Biol. Technol., 2013, 78(78), 67-75.

15 Z. Li, R. M. Adams, K. Chourey, G. B. Hurst, R. L. Hettich and C. Pan, J. Proteome Res., 2012, 11(3), 1582-1590.

16 P. M. Bramley and P. D. Fraser, Proteomics, 2013, 13(12-13), 2016-2030.

17 B. Zybailov, A. L. Mosley, M. E. Sardiu, M. K. Coleman, L. Florens and M. P. Washburn, J. Proteome Res., 2006, 5(9), 2339-2347.

18 N. M. Griffin, J. Yu, F. Long, P. Oh, S. Shore, Y. Li, et al., Nat. Biotechnol., 2010, 28(1), 83-89.

19 J. Wang, J. Pineal Res., 2016, 61(2), 138-153.

20 H. Chen, A. Xiujuan, Y. Mingliang, J. Li, M. Ruijuan, T. Mingmei and Y. Zhifang, Postharvest Biol. Technol., 2018, 145, 193-202.

21 P. N. Brown, S. J. Murch and P. Shipley, J. Agric. Food Chem., 2012, 60(1), 261-271.

22 M. C. Johnson, A. L. Thomas and C. M. Greenlief, J. Agric. Food Chem., 2015, 63(23), 5653.

23 C. M. Vâlcu and K. Schlink, Proteomics, 2006, 6(14), 41664175.

24 J. Cox, N. Neuhauser, A. Michalski, R. A. Scheltema, J. V. Olsen and M. Mann, J. Proteome Res., 2011, 10(4), 1794-1805.

25 J. Cox and M. Mann, Nat. Biotechnol., 2008, 26(12), 1367.

26 K. Eitner, U. Koch, T. Gaweda and J. Marciniak, Bioinformatics, 2010, 26(23), 2933-2935.

27 M. Q. Dong, J. D. Venable, N. Au, T. Xu, S. K. Park and D. Cociorva, Science, 2007, 317(5838), 660-663.

28 K. J. Livak and T. D. Schmittgen, Methods, 2001, 25(4), 402408.

29 B. V. D. Poel, T. Vandendriessche, M. L. A. T. M. Hertog, B. M. Nicolai and A. Geeraerd, Postharvest Biol. Technol., 2014, 95(3), 70-80.

30 L. Ji, J. Pang and S. Li, Afr. J. Biotechnol., 2012, 11(25), 67186722.

31 A. J. Keutgen and E. Pawelzik, Postharvest Biol. Technol., 2008, 49(1), 10-18.

32 Q. Han, H. Gao, H. Chen, X. Fang and W. Wu, Food Chem., 2017, 221, 1947-1953.

33 M. S. Aday and C. Caner, LWT-Food Sci. Technol., 2014, 57(1), 344-351.

34 M. Glowacz, R. Colgan and D. Rees, Postharvest Biol. Technol., 2015, 99, 1-8.

35 C. E. V. D. Oliveira, M. Magnani, C. V. D. Sales, A. L. D. S. Pontes, G. M. Campos-Takaki and E. L. D. Souza, Int. J. Food Microbiol., 2014, 171, 54-61.

36 A. Ali, M. K. Ong and C. F. Forney, Food Chem., 2014, 142, 1926. 
37 J. L. Smilanick, Packinghouse Newsletter, 2003, vol. 199, pp. 16.

38 B. R. Cordenunsi, M. I. Genovese, N. M. A. Hassimotto, R. J. D. Santos and F. M. Lajolo, Food Chem., 2005, 91(1), 113-121.

39 C. Pignocchi, J. M. Fletcher, J. E. Wilkinson, J. D. Barnes and C. H. Foyer, Plant Physiol., 2003, 132(3), 1631-1641.

40 D. F. Savage, B. Afonso, A. H. Chen and P. A. Silver, Science, 2010, 327(5970), 1258-1261.

41 M. A. Parry, P. J. Andralojc, J. C. Scales, M. E. Salvucci, A. E. Carmo-Silva and H. Alonso, J. Exp. Bot., 2013, 64(3), 717.

42 H. Ishihara, T. Obata, R. Sulpice, A. R. Fernie and M. Stitt, Plant Physiol., 2015, 168(1), 74-93.

43 R. Morita, M. Sugino, T. Hatanaka, S. Misoo and H. Fukayama, Plant Physiol., 2015, $167(4), 1321$.

44 C. S. Silva, W. D. Seider and N. Lior, Chem. Eng. Sci., 2015, 130, 151-171.

45 Y. Deng, A. B. Fisher and S. S. Fong, Appl. Microbiol. Biotechnol., 2015, 99(19), 8089-8100.

46 M. P. Sibi and J. Ji, Angew. Chem., Int. Ed., 1997, 36(3), 274276.

47 J. Potrykus, B. Mahaney, R. L. White and S. L. Bearne, Proteomics, 2007, 7(11), 1839-1853.

48 X. Yin, J. Li, H. D. Shin, G. Du, L. Liu and J. Chen, Biotechnol. Adv., 2015, 33(6), 830-841.

49 A. Karve, X. Xia and B. D. Moore, Plant Physiol., 2012, 158(4), 1965-1975.

50 C. Jungil, R. Nayeon, E. Joonseob, L. Daewoo, K. Hyunbi and J. Seokwon, Plant Physiol., 2009, 149(2), 745-759.
51 M. Decourcelle, L. Perez-Fons, S. Baulande, S. Steiger, L. Couvelard and S. Hem, J. Exp. Bot., 2015, 66(11), 3141.

52 E. Saavedra, R. Encalada, E. Pineda, R. Jasso-Chávez and R. Moreno-Sánchez, FEBS J., 2005, 272(7), 1767-1783.

53 L. Li, M. Wada and A. Yokota, Proteomics, 2007, 7(18), 3348. 54 C. Wu, W. Xiong, J. Dai and Q. Wu, Plant Physiol., 2015, 167(2), 586-599.

55 A. R. Fernie and P. R. U. Geigenberger, Plant Physiol., 2001, 125(4), 1967.

56 C. Anab, C. Elyana, P. Winterhalter, M. C. Garciaparrilla and A. M. Troncoso, Food Chem., 2010, 123(3), 574-582.

57 Q. Hua, Q. Zhou, S. Gan, J. Wu, C. Chen and J. Li, Int. J. Mol. Sci., 2016, 17(10), DOI: 10.3390/ijms17101606.

58 Y. Han, T. Ding, S. Bo and H. Jiang, Int. J. Mol. Sci., 2016, 17(2), 161.

59 M. Gall, M. Thomsen, C. Peters, I. V. Pavlidis, P. Jonczyk and P. P. GrüNert, Angew. Chem., Int. Ed., 2014, 53(5), 1439-1442.

60 P. Sangkyu, C. M. Ji, L. J. Yeol, K. J. Kwang, H. Sun-Hwa and L. Sun-Hyung, Int. J. Mol. Sci., 2016, $17(9), 1549$.

61 L. Ruiz-Vásquez, M. Reina, M. López-Rodríguez, C. Giménez, R. Cabrera and P. Cuadra, Phytochemistry, 2015, 117, 245253.

62 Z. Cai, R. Yang, H. Xiao, X. Qin and L. Si, Postharvest Biol. Technol., 2015, 100(100), 52-58.

63 R. Yokoyama, H. Kuki, T. Kuroha and K. Nishitani, Proteomes, 2016, 4(4), 34, DOI: 10.3390/proteomes4040034.

64 M. Glowacz, R. Colgan and D. Rees, J. Sci. Food Agric., 2015, 95(4), 662-671. 